\title{
Publisher Correction: Distance to range edge determines sensitivity to deforestation
}

C. David L. Orme, Sarah Mayor (D), Luiz dos Anjos, Pedro F. Develey, Jack H. Hatfield, José Carlos Morante-Filho, Jason M. Tylianakis (iD, Alexandre Uezu and Cristina Banks-Leite (iD)

Correction to: Nature Ecology \& Evolution https://doi.org/10.1038/s41559-019-0889-z, published online 06 May 2019.

In the version of this article originally published, the corresponding author was incorrect. Both C. David L. Orme and Cristina Banks-Leite were listed as corresponding authors. Only Cristina Banks-Leite should have been a corresponding author. The error has been corrected in the HTML and PDF versions of this article.

Published online: 11 June 2019

https://doi.org/10.1038/s41559-019-0932-0 